\title{
ADOPTION IN ENGLAND AND WALES
}

\author{
NICK CRICHTON
}

\section{CONTENTS}

A The Special Guardianship Order

Children need permanence, stability and a loving home where they are kept safe, both physically and emotionally. We all subscribe to that or we would not be working in family law and child protection. How we seek to deliver that when things are not right at home has been an ongoing debate across the world. I have had the privilege of undertaking some work in Australia from time to time, and I am aware that until now you have approved adoption only where the child's parents consent; and that adopted children continue to have quite regular contact with their birth parents. That is not the situation in England and Wales. However, the Family Justice Council will be holding its annual debate on 24 November 2015 at which precisely this issue will be on the table. This comment begins in Part I by outlining the historical and legislative context of adoption in England and Wales. Part II offers some observations on several different measures available in this jurisdiction aimed at ensuring that the interests of children are protected, including the Special Guardianship Order, which was introduced in 2005.

\section{ADOPTION IN ENGLAND AND WALES}

In England and Wales (Scotland is a different jurisdiction, although the situation in respect of adoption is broadly the same) the courts can order adoption without the consent of the birth parents. A judge can dispense with that consent if the child's parent cannot be found or lacks capacity; or if the court considers that the welfare of the child requires the consent to be 
dispensed with. Courts always have the welfare of the child in the forefront of their mind, and that includes having a clear focus on the individual child's timeframe. It is unhealthy for a child to languish in foster care for longer than is necessary - children need to be placed with the people who will care for them long-term as soon as is reasonably possible. Again this is a current 'hot topic', since the Government recently laid down that all care cases must be completed within 26 weeks. This provision was the result of too many children waiting too long for decisions to be made for them. Whilst it is a useful reminder that courts need to get on with it, many are concerned that the complexity of family problems (drug and alcohol misuse, mental health, personality disorder, domestic violence and abuse, housing problems, etc, etc) do not lend themselves to such a formulaic, man-made construct.

I believe it important to remember that:

1. The cohort of children available for adoption has changed considerably since the end of the Second World War. In the 1940s and 1950s there were many young, undamaged babies needing families. Illegitimacy was a stigma and young unmarried mothers were encouraged to give up their children at or soon after birth. Today the picture is very different. Most children needing adoptive families have already experienced abuse and/or neglect within their birth families. They are therefore older and more difficult to care for; and

2. The older the child the stronger will be his/her memory of his/her birth family. We know that children have a primal connection with their birth families, and that many who have been adopted seek out their birth families in later life. To adapt a phrase - 'you can take the child out of the birth family, but you can't take the birth family out of the child'.

I have read of the recommendation of the South Australia State Coroner following the tragic case of Chloe Valentine. We have suffered similar cases in our jurisdiction. Sadly no system is going to erase such cases altogether, but we have to keep trying. The trouble is that it is as much a tragedy to remove a child from his/her family unnecessarily as it is not do so when it clearly is necessary. Therefore we (social agencies and courts) need to deal with each situation on a case-by-case basis. Courts have the unenviable task of trying to find the right balance in each case between the parents' timeframe for recovery and the child's timeframe based on the need for that safe and permanent home. 
This is the point where I think it may be helpful if I include the bulk of s 1 of our Adoption and Children Act 2002 (UK):

\section{Considerations applying to the exercise of powers}

(1) This section applies whenever a court or adoption agency is coming to a decision relating to the adoption of a child.

(2) The paramount consideration of the court or adoption agency must be the child's welfare, throughout his life.

(3) The court or adoption agency must at all times bear in mind that, in general, any delay in coming to the decision is likely to prejudice the child's welfare.

(4) The court or adoption agency must have regard to the following matters (among others) -

(a) the child's ascertainable wishes and feelings regarding the decision (considered in the light of the child's age and understanding),

(b) the child's particular needs,

(c) the likely effect on the child (throughout his life) of having ceased to be a member of the original family and become an adopted person,

(d) the child's age, sex, background and any of the child's characteristics which the court or agency considers relevant,

(e) any harm (within the meaning of the Children Act 1989 (c. 41)) which the child has suffered or is at risk of suffering,

(f) the relationship which the child has with relatives, and with any other person in relation to whom the court or agency considers the relationship to be relevant, including-

(i) the likelihood of any such relationship continuing and the value to the child of its doing so,

(ii) the ability and willingness of any of the child's relatives, or of any such person, to provide the child with a secure environment in which the child can develop, and otherwise to meet the child's needs,

(iii) the wishes and feelings of any of the child's relatives, or of any such person, regarding the child.

(5) In placing the child for adoption, the adoption agency must give due consideration to the child's religious persuasion, racial origin and cultural and linguistic background. 
Sub-section (4) above is known as 'the adoption welfare checklist', and the court must demonstrate that it has worked through each heading and weighed up all the available information before arriving at its decision.

\section{PRotecting The INTERESTS OF CHILDREN}

It used to be the case that an adopted child was never told that he/she had been adopted (remember those post-war very small babies). Today it is thought important to be transparent about these issues, and children are told their beginnings from quite an early age. Social workers gather information from and about the birth family and foster families, together with photographs, which is put together in a 'Life Story Book' which the child will take with him/her into the adoptive placement. In this way the child is enabled to have good understanding of where they come from, how they arrived here, and does not feel that there are gaps in his/her knowledge and understanding.

In England and Wales we believe that some children are entitled to and need a completely fresh start — with a 'forever family'. Sometimes we believe that the older child - the one who has a clear memory of his/her birth family - should have some continuing contact with them. This may be by an exchange of correspondence and photographs, perhaps once or twice a year, or a meeting once or twice a year. This is not to enable the child to have a continuing relationship with the birth family, but rather so that the child has a sense of identity and can be reassured that his/her birth parents 'are OK' and perhaps in some cases to know that their parents are still thinking of them and wishing them well, even if they cannot care for them. Sometimes the birth parents are unable to make such contact meaningful for the child, or will try to undermine the placement. It isn't easy!

Long-term foster care can work well for some children, particularly the older children who need continuing contact with their birth families, and whose birth families do not seek to undermine the placement. However, many children feel stigmatised by being 'in care', and by still having social workers in their lives. I have had a number of children, particularly early teenagers, tell me how awful they feel when their social worker visits them at school.

\section{A The Special Guardianship Order}

In England and Wales we have a relatively new order — a Special Guardianship Order ('SGO'). This is a private law order, ie social services are no longer involved. It appoints one or more people to be the child's 
special guardian, and the guardian takes on all the responsibilities of a parent. They share those responsibilities with the birth parents, but they have the ultimate authority. These orders are useful where families and friends step in to care for a child, and in cases where religious and cultural beliefs cannot countenance adoption.

A SGO can be applied for by anyone who has the consent of those who have the legal parental responsibility for the child; anyone with the consent of the local authority if the child is in care; anyone with whom the child has lived for at least three of the last five years; or anyone who has the leave of the court. They do not have to be related to the child. Anyone applying for a SGO must give three months written notice of their intention to apply so that the responsible local authority can carry out an assessment of their suitability. Sometimes local authorities can be required to provide support and financial assistance to a special guardian, at least for the first three years. There are concerns that sometimes extended family members who would have taken on the care of children without the involvement of local authorities or courts apply for SGOs in order to obtain financial assistance from the local authority.

The purpose of the SGO is to provide the child with the necessary permanence and security even though adoption may not be suitable in the particular case. The fundamental legal links with the birth family are preserved, and the court has to consider whether it is necessary to make an order for contact with the birth parents. The SGO extinguishes any public law orders, ie if the child is the subject of a care or supervision order in favour of a local authority.

Research is currently being undertaken into the effectiveness and efficacy of SGOs. There can be no 'one-size-fits-all'. That is why we must deal with each case on its individual facts and merits, always acting in the best interests of this child - and always remembering that children benefit from permanence and security. 